\title{
CHANGES IN THE DIVERSITY OF DRY CALCAREOUS GRASSLANDS AFTER ABANDONMENT OF TRADITIONAL MANAGEMENT IN DEVÍNSKA KOBYLA NATIONAL NATURE RESERVE (SOUTHWESTERN SLOVAKIA, CENTRAL EUROPE)
}

\author{
ALENA RENDEKOVÁ ${ }^{1 *}$, JÁN MIŠKOVIC ${ }^{1}$, KAROL MIČIETA ${ }^{1}$, MARTINA MICHALO- \\ VÁ ${ }^{1}$, MARIANA ELIAŠOVÁ ${ }^{2}$ DOMINIKA BALLOVÁ ${ }^{3}$ \\ ${ }^{1}$ Department of Botany, Faculty of Natural Sciences, Comenius University in Bratislava, Révová 39, 81102 Bratislava, \\ Slovak Republic; e-mail: alenarendekova@gmail.com \\ ${ }^{2}$ Department of Ecology, Slovak University of Agriculture, Mariánska 10, 94901 Nitra, Slovak Republic \\ ${ }^{3}$ Department of Mathematics and Descriptive Geometry, Faculty of Civil Engineering, Slovak University of Technology \\ in Bratislava, Radlinského 11, 81005 Bratislava, Slovak Republic
}

* Author for correspondence

\begin{abstract}
Rendeková A., Miškovic J., Mičieta K., Michalová M., Eliašová M., Ballová D.: Changes in the diversity of dry calcareous grasslands after abandonment of traditional management in Devínska Kobyla National Nature Reserve (Southwestern Slovakia, Central Europe). Ekológia (Bratislava), Vol. 39, No. 2, p. 101-115, 2020.

This study is focused on the evaluation of the values of the diversity indices of semi-natural dry calcareous grasslands of the Festuco-Brometea class in the area of Devínska Kobyla National Nature Reserve 50 years after abandonment of traditional management (grazing and mowing). The values of the species richness, the Shannon-Wiener index of diversity, the Simpson index, and Pielou's measure of species evenness in the communities in the old and recent data, and the values of the environmental variables based on the Ellenberg indicator values of species were analyzed. For most of these analyses, we used Kruskal-Wallis in R 3.5.1. Compared to the past, we have recorded a significant lower values of the species richness, biodiversity, and species evenness in some communities. In some communities, no significant changes were recorded. Only in one community-Poo badensis-Festucetum pallentis, the higher values of Shannon-Wiener index was recorded compared to the past. The analysis of the Ellenberg indicator values revealed a statistically significant higher Ellenberg indicator values for moisture and nutrients and lower values for light in more recent period compared to the old period. The recorded results could be caused by the changes in the management after the year 1965, after abandonment of grazing and the gradual overgrowing by woody species took place in the area. The frequency of occurrence of some woody species (e.g., Populus alba, P. nigra, and Robinia pseudoacacia) in some communities increased compared to the past.
\end{abstract}

Key words: Devínska Kobyla Mts, Festuco-Brometea, succession, vegetation biodiversity conservation. 


\section{Introduction}

Semi-natural dry calcareous grasslands (Festuco-Brometea class) have spread in Central Europe after forest clearing and consecutive traditional land use such as grazing and mowing (Poschlod, WallisDeVries, 2002; Chytrý, 2007). These specific habitats cannot exist without the repeated removal of biomass by grazing, mowing, burning, or by other ways and control of species not adapted to such disturbance regimes. Formation of dry grasslands is influenced by these disturbances and stress caused by extreme habitat conditions (low content of nutrients, low humidity, and high temperature), which allows the existence of many adapted species indirectly by limiting the growth of competitively stronger species (Kubíková, 1999; Münzbergová, 2001; Chytrý, 2007). Because of disturbance regime and long history of development, dry calcareous grasslands belong to the most species-rich types of vegetation ever (Willems, 1983; During, Willems, 1984; Bobbink et al., 1987; Poschlod, WallisDeVries, 2002; Chytrý, 2007; Schrautzer et al., 2009). They also harbor a large number of endangered species (Wolkinger, Plank, 1981; Pipenbaher et al., 2013).

The abandonment of traditional forms of land use such as grazing and mowing over the last decades has brought an increasing concern about the consequences of the resulting expansion of shrubs and trees on species-rich dry calcareous grasslands (Dzwonko, Loster, 1998; Hansson, Fogelfors, 2000; Willems, 2001; Bąba, 2003; Alard et al., 2005; Köhler et al., 2005; Dostálek, Frantík, 2008; Schrautzer et al., 2009; Jacquemyn et al., 2010; Ruprecht et al., 2010; Török, Szitár, 2010; Tälle et al., 2018). Some studies have shown that the abandonment of traditional land use had negative impact on the species richness, diversity, and area of dry grasslands in Central Europe (Poschlod, WallisDeVries, 2002; Galvánek, Lepš, 2008; Schrautzer et al., 2009; Hegedüšová, Senko, 2011; Pipenbaher et al., 2013), and in the last few years, more attention is being devoted to conservation management (Poschlod et al., 1998; Barbaro et al., 2001; Münzbergová, 2001; Willems, 2001; Kahmen et al., 2002; Riecken et al., 2002; WallisDeVries et al., 2002; Bąba, 2004; Masé, 2005; Bornkamm, 2006; Stadler et al., 2007; Dostálek, Frantík, 2008; Peter et al., 2009; Kuzemko et al., 2016). The importance of conservation management and maintenance of traditional ways of farming is visible not only in the case of grasslands but also in the case of various other types of habitats (Mojses, Petrovič, 2013; Špulerová et al., 2016) and other scientists have also devoted their research to changes in various types of vegetation (Palaj, Kollár, 2018).

Devínska Kobyla Mt. (southern part of Male Karpaty Mts., Slovakia, Central Europe) is a unique area with specific environmental conditions. Dry grasslands at Devínska Kobyla Mt. have formed due to agricultural activity and deforestation of the area (Kaleta, 1965; Hajdúk, 1986). Grazing by goats and sheep and mowing were the main factors that influenced the development and the maintenance of the species-rich dry grassland communities at the area. During the mid-20th century, the traditional land use such as grazing, mowing, and burning was ceased. The gradual expansion of shrubs and trees took place in the area (Hegedüšová, Senko, 2011).

Dry grasslands in Devínska Kobyla were studied by Domin (1931); Kaleta (1965); Michalko (1977); Hajdúk (1986); Baláž (1994); Hajdúk (1997); Maliníková (2003), Miškovic, 
Dúbravcová (2004a;b); Zlínska (2004); Senko et al. (2008) and Hegedüšová, Valachovič (2015). Hegedüšová and Senko (2011) reported changes in species composition of dry grasslands in Devínska Kobyla Mt., but they did not pay attention to changes in diversity indices and environmental conditions. Our study overcomes this gap and also bring new results from survey performed in the last years and help in the management of protected area. The aim of this study is to assess the values of the diversity indices in reference (1964) and recent (2012-2018) phytosociological data. Hypothesis: we expected that the values of the species richness, Shannon-Wiener index of diversity, Simpson index, and Pielou's measure of species evenness in vegetation would be lower in comparison to the past, because of previously mentioned abandonment of traditional management of the area.

\section{Material and methods}

\section{Study area}

Devínska Kobyla National Nature Reserve is located on the southwestern and western slopes of the Devínska Kobyla Mt., which is the southernmost part of the Little Carpathians Mts. (Slovakia, Central Europe). The entire massif of Devínska Kobyla is part of the Malé Karpaty Protected Landscape Area. In 1964, the Devínska Kobyla State Nature Reserve was established to protect thermo-xerophilous habitats covering the area of $27.97 \mathrm{ha}$. Later, in 1986, it was enlarged to its current area of $101.12 \mathrm{ha}$. On the basis of later legal regulations, the reserve was included in the list of national nature reserves under the currently valid name Devínska Kobyla National Nature Reserve (Feráková, Kocianová, 1997).

There is an unusual variety of environmental phenomena concentrated on the area of Devínska Kobyla. It is unique because of its geographical position, history, extraordinary environmental conditions such as topography and climate, and mainly because of its thermophilous grassland- and forest-steppe flora and vegetation (Feráková, Kocianová, 1997; Hegedüšová, Valachovič, 2015).

The study area belongs to the warm climatic region, and it is one of the warmest and driest parts of Slovakia. It has an average 50 summer days per year or more, with a daily maximum temperature of $25^{\circ} \mathrm{C}$ and higher. The average duration of sunshine is one of the longest in Slovakia (in the vegetation period, it is $60 \%=1,600 \mathrm{~h}$ ) (Feráková, Jarolímek, 2011).

The most common soil types in the Devínska Kobyla NNR are Cambisols (Calcaric) and Rendzic Leptosol, on deluvium of carbonate-silicate weathered rock. On a smaller area, especially in the territories with the local names Sandberg and Merice, occur soil types Haplic Regosol (Calcaric) on neogene sand and sandstones, while on weathered limestones and dolomites dominate Rendzic Leptosol and Lithic Leptosol. Rarity in the territory of Devínska Kobyla NNR is the occurrence of 1 ha of soils formed on the loess, namely Cutanic Luvisols and Haplic Chernozem, as well as several cubic meters of Rendzic Leptosol on the weathered Tertiary calcareous conglomerates (Feráková, Jarolímek, 2011).

The Devínska Kobyla NNR is also known by the near proximity of a well-known paleontological site Sandberg. It is the old sandpit, where remnants of rocks of the Tertiary Sea, Miocene marine, and nonmarine sediments are situated. The horizontally deposited layers of the Tertiary sea with the estimated age of 14-16 million years can be found here. Fossils of the sea fauna were conserved in Sandberg (Feráková, Kocianová, 1997; Hyžný et al., 2012).

\section{Data source}

We have analyzed 153 phytosociological relevés of dry grassland communities of Festuco-Brometea class, which includes the dry grassland vegetation of the Eurosiberian steppes and warm regions in the temperate zone of Europe. These plant communities are dominated by grasses and have high proportion of dicotyledonous perennial herbs. They usually grow on nutrient poor calcareous soils and developed secondary on areas of former forests (Chytrý, 2007). We used the relevés of four associations from the Festuco-Brometea class: Poo badensis-Festucetum pallentis, Festuco pallentis-Caricetum humilis, Festuco valesiacae-Stipetum capillatae, and Polygalo majoris-Brachypodietum pinnati; grasslands of these four associations cover most of the area of Devínska Kobyla NNR. The Poo badensis- 
Festucetum pallentis association includes open dry grassland communities growing on shallow dry soils on the steep slopes. The stands of the Festuco pallentis-Caricetum humilis association usually grow on shallow to moderately deep soils, and the Festuco valesiacae-Stipetum capillatae occurs on deeper soils. Among the four analyzed associations, the stands of the Polygalo majoris-Brachypodietum pinnati association grow on the relatively deepest soils (Chytrý, 2007; Hegedüšová-Vantarová, Škodová, 2014).

The data were sampled during two time periods with the time span of $\sim 50$ years. Data (40 relevés) sampled in 1964 (Kaleta, 1965) are used as reference data (Fig. 1). Recent data (113 relevés) were sampled in 2012-2018 (Miškovic, 2018) (Fig. 2). The number of recorded relevés in the studied vegetation types was as follows: Poo badensis-Festucetum pallentis-8 old relevés and 36 recent relevés, Festuco pallentis-Caricetum humilis-8 old relevés and 22 recent relevés, Festuco valesiacae-Stipetum capillatae-12 old relevés and 6 recent relevés, and Polygalo majorisBrachypodietum pinnati-12 old relevés and 49 recent relevés.

The recent plot sizes corresponded to old plot sizes (Kaleta, 1965) and the plot size of $25 \mathrm{~m}^{2}$ was used. We tried to sample some relevés in 2012-2018 at the same localities as old relevés. This could be done in the case of 20 relevés, but we were not able to do this in the case of all relevés because of the absence of permanent plots in historical research. Since Devínska Kobyla is a relatively small area, the possibility of mistakes was low. Because of the missing permanent plots, we did more new relevés, which made the research more precise and this could also eliminated mistakes. The same process of plot selection as used in old time period was used to obtain comparable dataset. The relevés were sampled according to the actual occurrence and distribution of the communities with the intention to record all types of dry grasslands and cover entire area of reserve. The phytosociological research in both time periods was performed according to the methodology of the Zürich-Montpellier school (Braun-Blanquet, 1964). In 1964, the old Braun-Blanquet cover-abundance scale was used. In 2000-2018, the modified Braun-Blanquet cover-abundance scale was used, extended by categories $2 \mathrm{~m}$ (cover 1-5\%, abundance high), 2a (cover 5-12.5\%), and 2b (cover 12.5-25\%) values (Barkman et al., 1964).

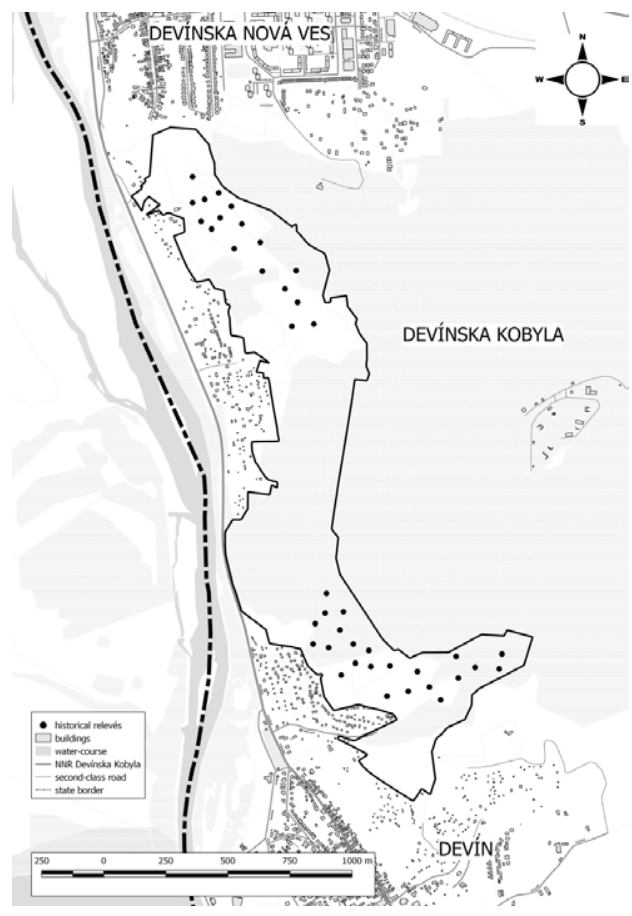

Fig. 1. Distribution of recorded relevés in the study area in 1964.

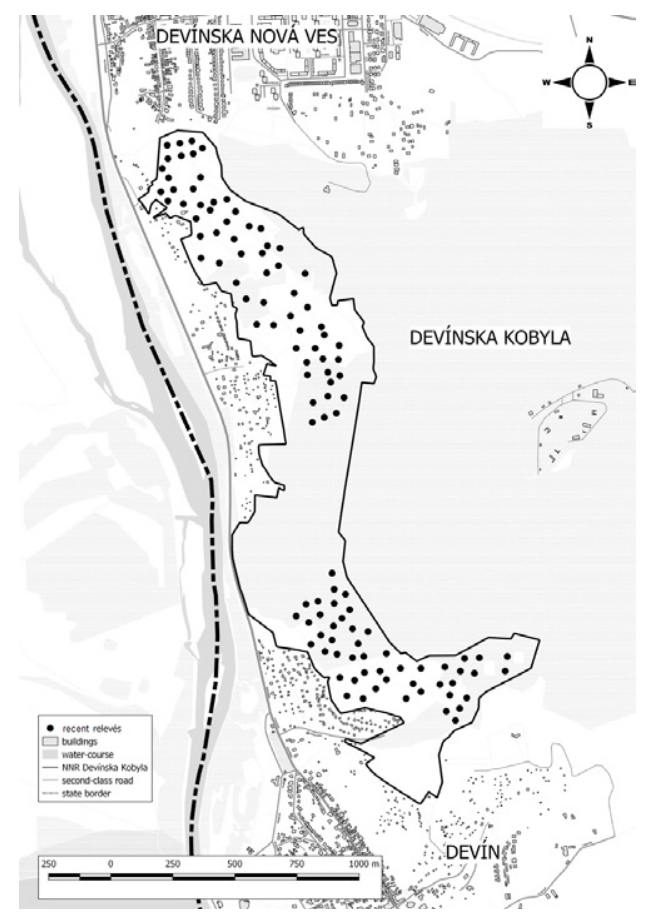

Fig. 2. Distribution of recorded relevés in the study area in the years 2012-2018. 
Relevés were imported into a TURBOVEG database (Hennekens, Schaminée, 2001) and analyzed in the program JUICE (Tichý, 2002). Bryophytes, lichens, and taxa of vascular plants determined only to the genus level were excluded from the analysis. Taxa that occurred in more than one layer were merged. Some taxonomically problematic species were merged to higher or more broadly defined taxa: Achillea millefolium agg. (A. collina Becker ex Rchb., A. millefolium L., A. pannonica Scheele, and A. setacea Waldst. et Kit.), Arenaria serpyllifolia agg. (A. leptoclados (Rchb.) Guss. and A. serpyllifolia L.), Erophila verna agg. (E. spathulata Láng and E. verna (L.) Chevall), Erysimum diffusum agg. (E. andrzejowskianum Besser and E. diffusum Ehrh.), Galium mollugo agg. (G. album Mill. and G. mollugo L.), Lotus corniculatus agg. (L. borbasii Ujhelyi, L. corniculatus L. and L. tenuis Waldst. et Kit. ex Willd.), and Poa pratensis agg. (P. angustifolia L. and P. pratensis L.). Because different cover-abundance scales have been used in old and recent relevés, the values $2 \mathrm{~m}, 2 \mathrm{a}$, and $2 \mathrm{~b}$ in both datasets were converted to value 2 .

Phytosociological relevés were analyzed by numerical classification (cluster analysis) in the program SYN-TAX 2000 (Podani, 2001). Data were not transformed. The Group average method in combination with Ružička's coefficient proved to be the most effective linkage method and distance measure and the results obtained by them corresponded to our field experience. Clusters were assigned to associations by diagnostic species (Jarolímek, Šibík, 2008; Hegedüšová-Vantarová, Škodová, 2014) and by electronic expert system for identification of syntaxa of grassland vegetation (Janišová, 2007).

The species richness (number of species), the Shannon-Wiener index of diversity $\left[H^{\prime}\right]$ (Hill, 1973), the Simpson index (Hill, 1973), and the Pielou's measure of species evenness $\left[J=H^{\prime} / \ln (S)\right.$, where $H^{\prime}$ is the Shannon diversity index and $S$ is the number of taxa per relevé] were calculated for each relevé in the program JUICE. Subsequently, the number of species and the values of indices were calculated for each association, both for reference and recent time periods. The normality of data distribution was tested by Shapiro-Wilk test. As the data were not normally distributed, the Kruskal-Wallis analysis in R 3.5.1 (R Core Team, 2018) was applied to test the differences in these values between the periods in each association and also in whole dataset.

As an explanatory variable to show possible changes in vegetation ecological characteristics, the Ellenberg indicator values for light, temperature, continentality, moisture, soil reaction, and nutrients (Ellenberg et al., 1992) based on species presence were calculated, using the program JUICE. We analyzed the Ellenberg indicator values in total old and recent datasets (all associations together) using the Kruskal-Wallis analysis in R 3.5.1 (R Core Team, 2018), because by testing the Ellenberg indicator values between the two time periods and associations differences were found not significant.

Nomenclature

The nomenclature of taxa follows Marhold (1998), and the nomenclature of syntaxa follows Hegedüšová-Vantarová, Škodová (2014).

\section{Results}

The hypothesis was confirmed in the case of some associations (Table 1). The Kruskal-Wallis analysis revealed a statistically significant lower values of the median of species richness in recent relevés from the association Festuco pallentis-Caricetum humilis ( $p=0.0002$, level of significance $\alpha=0.05, \chi^{2}=13.77$ ) and from the association Polygalo majoris-Brachypodietum pinnati ( $\left.p=0.0002, \alpha=0.05, \chi^{2}=13.44\right)$ compared to old relevés (Table 2 and Fig. 3 ).

The values of the median of Shannon-Wiener index of diversity were significantly lower over time in the association Polygalo majoris-Brachypodietum pinnati $\left(p=0.001, \alpha=0.05, \chi^{2}\right.$ $=11.10$ ) (Table 2 and Fig. 4).

The median values of Simpson index were significantly lower in the association Polygalo majoris-Brachypodietum pinnati $\left(p=0.0001, \alpha=0.05, \chi^{2}=14.68\right)$ (Table 2 and Fig. 5).

The median values of Pielou's measure of species evenness were significantly lower in the associations Poo badensis-Festucetum pallentis $\left(p=0.0039, \alpha=0.05, \chi^{2}=8.35\right)$ and Polygalo majoris-Brachypodietum pinnati ( $\left.p=0.0047, \alpha=0.05, \chi^{2}=7.98\right)$ (Table 2 and Fig. 6 ). 
$\mathrm{T}$ a b l e 1. Summarization of significancy of the results of analysis of differences in the biodiversity in the associations between the old and recent data.

\begin{tabular}{|l|c|c|c|c|}
\hline & $\begin{array}{c}\text { Poo badensis- } \\
\text { Festucetum pallentis }\end{array}$ & $\begin{array}{c}\text { Festuco pallentis- } \\
\text { Caricetum humilis }\end{array}$ & $\begin{array}{c}\text { Festuco valesiacae- } \\
\text { Stipetum capillatae }\end{array}$ & $\begin{array}{c}\text { Polygalo majoris- } \\
\text { Brachypodietum } \\
\text { pinnati }\end{array}$ \\
\hline Species richness & $\begin{array}{c}\text { No significant } \\
\text { difference }\end{array}$ & Significantly lower & $\begin{array}{c}\text { No significant } \\
\text { difference }\end{array}$ & Significantly lower \\
\hline $\begin{array}{l}\text { Shannon-Wiener } \\
\text { index of diversity }\end{array}$ & Significantly higher & $\begin{array}{c}\text { No significant } \\
\text { difference }\end{array}$ & $\begin{array}{c}\text { No significant } \\
\text { difference }\end{array}$ & Significantly lower \\
\hline Simpson index & $\begin{array}{c}\text { No significant } \\
\text { difference }\end{array}$ & $\begin{array}{c}\text { No significant } \\
\text { difference }\end{array}$ & $\begin{array}{c}\text { No significant } \\
\text { difference }\end{array}$ & Significantly lower \\
\hline $\begin{array}{l}\text { Pielou's measure } \\
\text { of species evenness }\end{array}$ & Significantly lower & $\begin{array}{c}\text { No significant } \\
\text { difference }\end{array}$ & $\begin{array}{c}\text { No significant } \\
\text { difference }\end{array}$ & Significantly lower \\
\hline
\end{tabular}

T a b l e 2. Results of Kruskal-Wallis analysis testing differences in the species richness and diversity indices in the communities between the old and recent data.

\begin{tabular}{|c|c|c|c|}
\hline Association & $\chi^{2}$ & p Value & Significancy \\
\hline \multicolumn{4}{|c|}{ Species richness } \\
\hline Poo badensis-Festucetum pallentis & 0.81 & 0.37 & $\mathrm{NO}$ \\
\hline Festuco pallentis-Caricetum humilis & 13.77 & 0.0002 & YES \\
\hline Festuco valesiacae-Stipetum capillatae & 0.05 & 0.82 & NO \\
\hline Polygalo majoris-Brachypodietum pinnati & 13.44 & 0.0002 & YES \\
\hline \multicolumn{4}{|c|}{ Shannon-Wiener index of diversity $\left[H^{\star}\right]$} \\
\hline Poo badensis-Festucetum pallentis & 7.38 & 0.01 & YES \\
\hline Festuco pallentis-Caricetum humilis & 1.01 & 0.32 & NO \\
\hline Festuco valesiacae-Stipetum capillatae & 0.001 & 0.98 & NO \\
\hline Polygalo majoris-Brachypodietum pinnati & 11.10 & 0.001 & YES \\
\hline \multicolumn{4}{|c|}{ Simpson index } \\
\hline Poo badensis-Festucetum pallentis & 0.03 & 0.87 & NO \\
\hline Festuco pallentis-Caricetum humilis & 0.70 & 0.40 & NO \\
\hline Festuco valesiacae-Stipetum capillatae & 0.08 & 0.78 & NO \\
\hline Polygalo majoris-Brachypodietum pinnati & 14.68 & 0.0001 & YES \\
\hline \multicolumn{4}{|c|}{ Pielou's measure of species evenness } \\
\hline Poo badensis-Festucetum pallentis & 8.35 & 0.004 & YES \\
\hline Festuco pallentis-Caricetum humilis & 0.04 & 0.83 & NO \\
\hline Festuco valesiacae-Stipetum capillatae & 0.01 & 0.99 & NO \\
\hline Polygalo majoris-Brachypodietum pinnati & 7.98 & 0.005 & YES \\
\hline
\end{tabular}

The median values of Shannon-Wiener index of diversity were higher in the association Poo badensis-Festucetum pallentis ( $p=0.01, \alpha=0.05, \chi^{2}=7.38$ ) (Table 2 and Fig. 4).

The differences in values in the median of species richness and indices in other associations were not statistically significant (Tables 1,2 ).

By Kruskal-Wallis analysis of differences in Ellenberg indicator values between old and recent relevés of the studied associations, no statistically significant results were obtained 

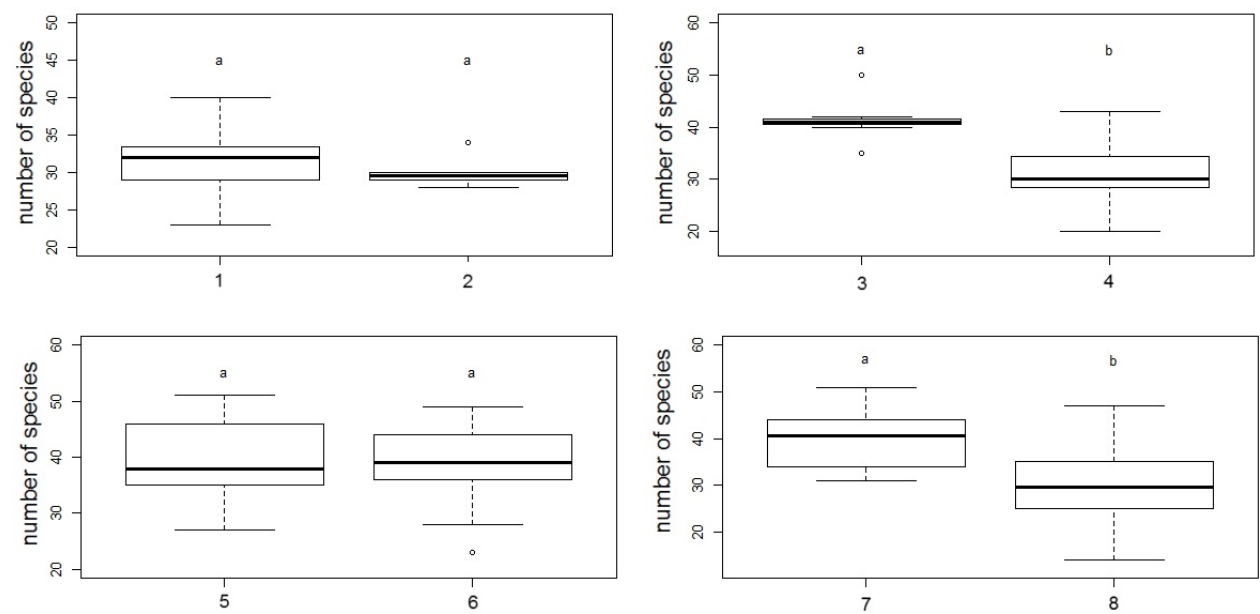

Fig. 3. The species richness of the old and recent relevés of studied vegetation types of Devínska Kobyla. Notes: - $\square$ median; 025 75\%; I min-max; o outliers; a b - significant difference; a a - not significant difference;

1 - Poo badensis-Festucetum pallentis, reference relevés-1964 (Kaleta, 1965);

2 - Poo badensis-Festucetum pallentis, recent relevés-2000-2018 (Miškovic, 2018);

3 - Festuco pallentis-Caricetum humilis, reference relevés-1964 (Kaleta, 1965);

4 - Festuco pallentis-Caricetum humilis, recent relevés-2000-2018 (Miškovic, 2018);

5 - Festuco valesiacae-Stipetum capillatae, reference relevés-1964 (Kaleta, 1965);

6 - Festuco valesiacae-Stipetum capillatae, recent relevés-2000-2018 (Miškovic, 2018);

7 - Polygalo majoris-Brachypodietum pinnati, reference relevés-1964 (Kaleta, 1965);

8 - Polygalo majoris-Brachypodietum pinnati, recent relevés-2000-2018 (Miškovic, 2018).
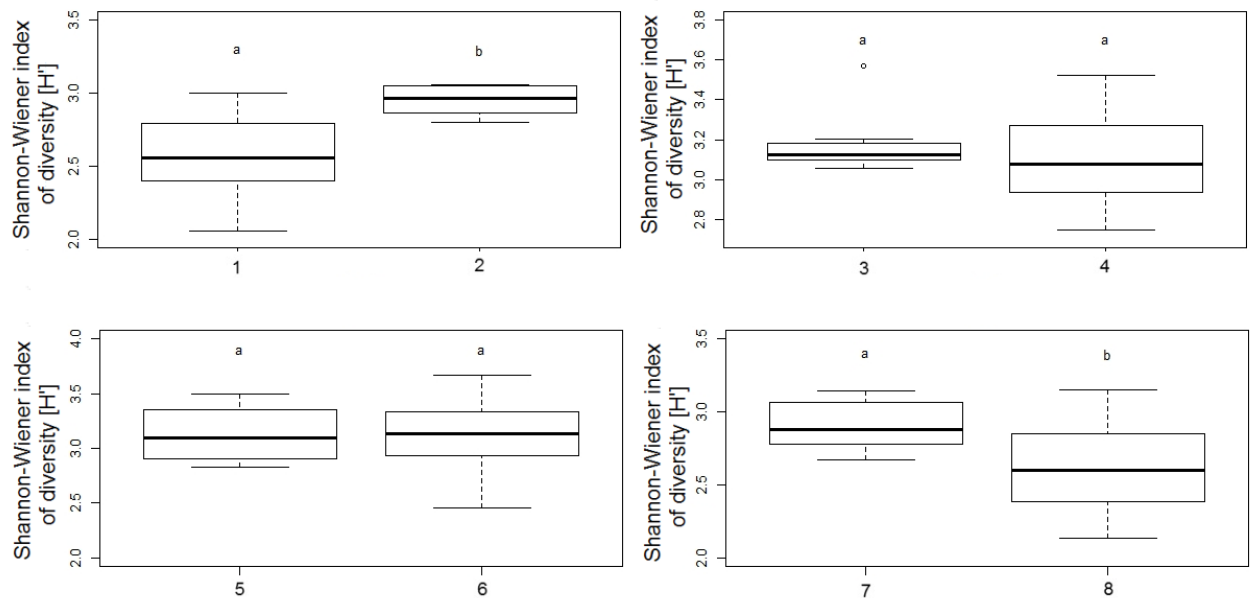

Fig. 4. The Shannon-Wiener index of diversity $\left[H^{\prime}\right]$ for the old and recent relevés of studied vegetation types of Devínska Kobyla. Explanation corresponds to those in Figure 3. 

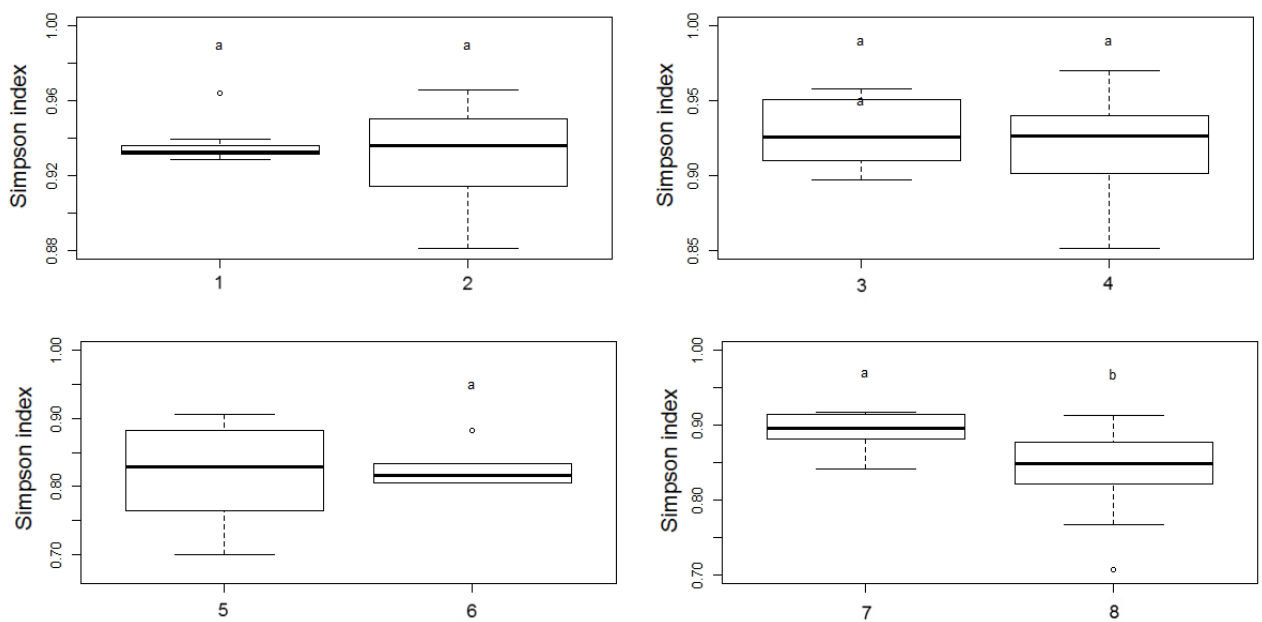

Fig. 5. The Simpson index for the old and recent relevés of studied vegetation types of Devínska Kobyla. Explanation corresponds to those in Figure 3.
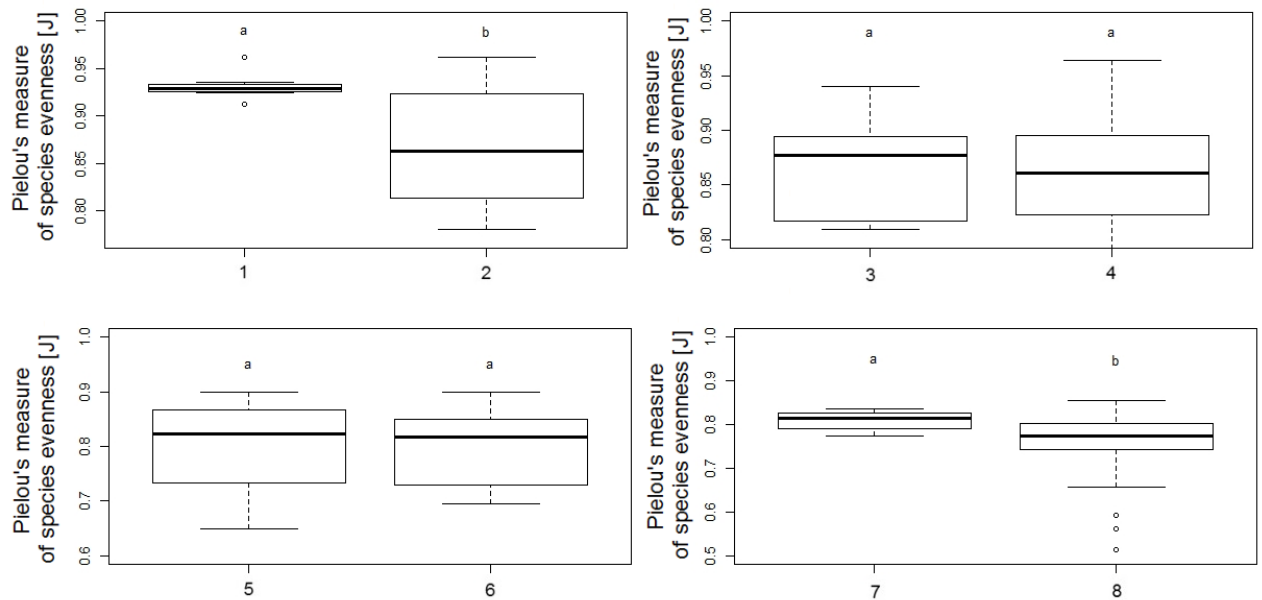

Fig. 6. The Pielou's measure of species evenness for the old and recent relevés of studied vegetation types of Devínska Kobyla. Explanation corresponds to those in Figure 3.

(Table 3). The analysis of the Ellenberg indicator values in total dry grassland vegetation by Kruskal-Wallis analysis revealed a statistically significant lower Ellenberg values for light in recent period compared to the past $\left(\mathrm{p}=0.004, \alpha=0.05, \chi^{2}=8.5\right)$ (Table 3 and Fig. 7a). There was no significant difference in Ellenberg indicator values for temperature (Fig. 7b), conti- 
nentality (Fig. 7c). The analysis revealed a significant higher Ellenberg indicator values for moisture ( $\mathrm{p}=0.01, \alpha=0.05, \chi^{2}=6.2$ ) (Table 3 and Fig. $7 \mathrm{~d}$ ). There was no significant difference in Ellenberg indicator values for soil reaction (Fig. 7e) between past and recent period. There were a significant higher Ellenberg indicator values for nutrients $(p=0.0001, \alpha=0.05$,

$\mathrm{T}$ a b l e 3. Results of Kruskal-Wallis analysis testing differences in the Ellenberg indicator values between the old and recent data.

\begin{tabular}{|l|c|c|c|}
\hline & $\boldsymbol{\chi}^{\mathbf{2}}$ & $\boldsymbol{p}$ Value & Significancy \\
\hline Light & 8.45 & $\mathbf{0 . 0 0 4}$ & YES \\
\hline Temperature & 0.99 & 0.32 & NO \\
\hline Continentality & 1.49 & 0.22 & NO \\
\hline Moisture & 6.2 & $\mathbf{0 . 0 1}$ & YES \\
\hline Soil reaction & 1.59 & 0.21 & NO \\
\hline Nutrients & 15.8 & $\mathbf{0 . 0 0 0 1}$ & YES \\
\hline
\end{tabular}
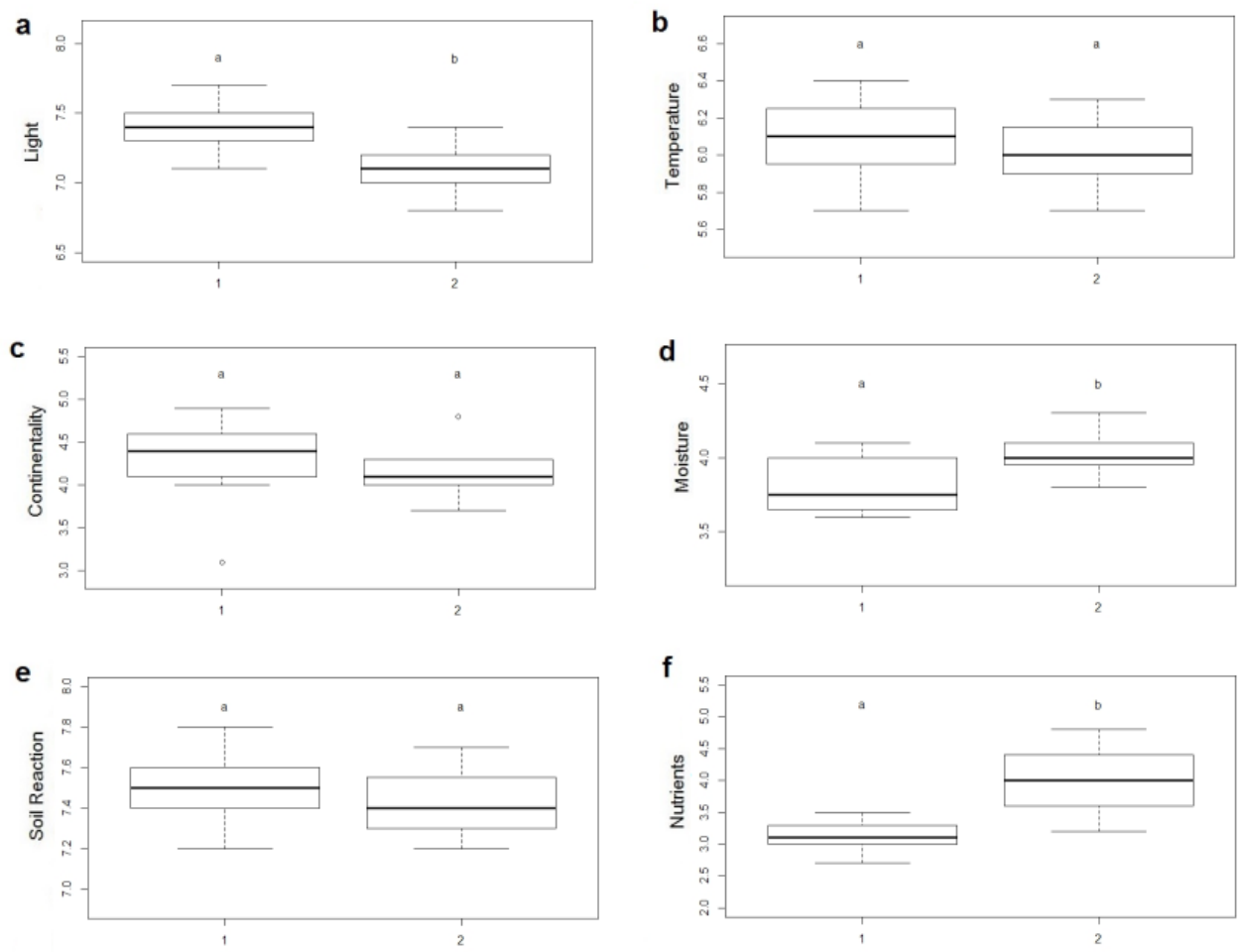

Fig. 7. The Ellenberg indicator values for light (a), temperature (b), continentality (c), moisture (d), soil reaction (e), and nutrients (f) for the reference (year 1964) and recent (years 2000-2018) relevés.

Notes: 1 - reference relevés (1964); 2 - recent relevés (2000-2018); a b -significant difference; a a -not significant difference; - median; 025 75\%; I min-max; o outliers. 
$\mathrm{T}$ a b l e 4. Frequency of occurrence and cover range of woody species in recent relevés (2000-2018), which were not recorded in the past (1964)

\begin{tabular}{|l|c|c|}
\hline & Pb-Fp & Pm-Bp \\
\hline Cornus mas & - & $10^{1}$ \\
\hline Fraxinus ornus & - & $6^{+-2}$ \\
\hline Pinus sylvestris & $6^{+}$ & - \\
\hline Populus alba & $11^{2-3}$ & - \\
\hline Populus nigra & $11^{+-2}$ & - \\
\hline Robinia pseudoacacia & $3^{2}$ & - \\
\hline Swida sanguinea & $8^{1-2}$ & $4^{+}$ \\
\hline Ulmus minor & - & $4^{+}$ \\
\hline
\end{tabular}

Notes: The numbers given in the table are frequency values of a species for a particular vegetation type; their upper indices represent the cover range of species. $\mathrm{Pb}-\mathrm{Fp}$-Poo badensis-Festucetum pallentis and Pm-Bp-Polygalo majoris-Brachypodietum pinnati. $\left.\chi^{2}=15.8\right)$ in recent period compared to the past (Table 3 and Fig. 7f).

As an explanatory feature we present the table with the values of frequency of occurrence and cover range of woody species in recent relevés (2000-2018), which were not recorded in the past (1964) (Table 4). The numbers given in the table are frequency values of a species for a particular vegetation type and their upper indices represent the cover range of species. The frequency of occurence of some woody species increased in associations $P o o$ badensis-Festucetum pallentis and Polygalo majoris-Brachypodietum pinnati (Table 4).

\section{Discussion}

The majority of significant results of analyses revealed the lower values of species richness, diversity, and evenness in studied dry grassland communities of Devínska Kobyla in recent period compared to the past (Tables 1,d 2 and Figs 3-6). This decline of values of diversity indices is probably caused mainly by the abandonment of traditional land use (grazing and mowing) in the area after 1965, because the disturbances caused by grazing and mowing are necessary for the maintenance of the species richness and diversity of dry grasslands (Kubíková, 1999; Münzbergová, 2001; Chytrý, 2007; Galvánek, Lepš, 2008).

The significant higher values in recent period were recorded only in the case of Shannon-Wiener in one association-Poo badensis-Festucetum pallentis (Table 2 and Fig. 4). Hegedüšová, Senko (2011) in study from Devínska Kobyla found out that species richness in this association declined over time, which is in the contrast with our result of increase in Shannon-Wiener index. Hegedüšová, Senko (2011) recorded the increase of species richness in the other association-Festuco valesiacae-Stipetum capillatae. Authors consider Festuco valesiacae-Stipetum capillatae the least endangered by successional changes.

We did not record significant differences of any diversity index in the association Festuco valesiacae-Stipetum capillatae between old and recent data. The possible reason can be that the association is species rich and grows on relatively steeper soils, where succession is slower than in deeper soils, where grows the association Polygalo majoris-Brachypodietum pinnati, which showed decrease of all diversity indices.

The explanation of the higher diversity index in the association Poo badensis-Festucetum pallentis in recent period can be that this association occurs on rocks with the shallowest soils, where significant changes in management did not occur. There were no grazing or 
mowing in the rocky shallow soil in the past. That could be the reason why this association is less endangered by successional changes after abandonment of traditional management than other analyzed associations, which grow on sites with deeper soil, where management changes occurred. On the other hand, it is still a fact that some changes occurred also in the association Poo badensisFestucetum pallentis, for example, overgrowing

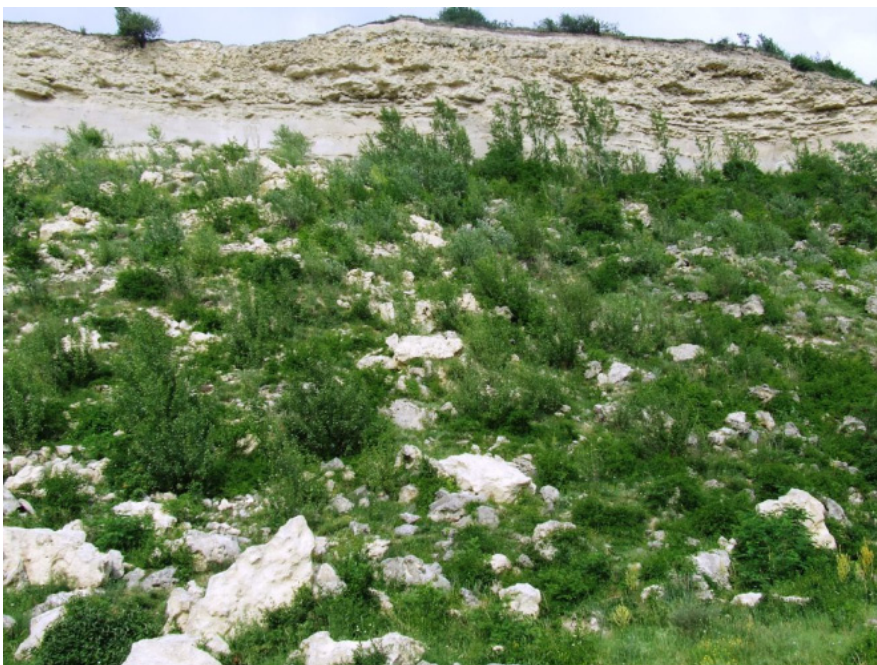

Fig. 8. Overgrowing by woody species in the stands of the association Poo badensis-Festucetum pallentis at Sandberg, Devínska Kobyla (Author of photo: Ján Miškovic). by woody species (Table 4).

Although no significant differences of the Ellenberg indicator values between old and recent period were found for some of the environmental variables, the Ellenberg indicator values for nutrients and moisture were significantly higher in recent period (Fig. 7). This result could have connection with overgrowing by woody species and increased accumulation of died biomass after abandonment and its increased decomposition, and thus enrichments of soils by nutrients. Similar results were achieved by Ruprecht et al. (2010), and the accumulation of biomass is a consequence of abandonment of grasslands. After the abandonment of the traditional management, the gradual overgrowing by woody species took place in the Devínska Kobyla (Hegedüšová, Senko, 2011). The frequency of occurrence of some woody species was higher in the recent relevés from the associations Poo badensis-Festucetum pallentis and Polygalo majoris-Brachypodietum pinnati (Table 4). The overgrowing by species such as Populus alba, P. nigra, and invasive species Robinia pseudoacacia in the stands of the Poo badensis-Festucetum pallentis association in Devínska Kobyla is also evident in the photography from the studied area (Fig. 8). The stands of Poo badensis-Festucetum pallentis are open (average total cover of species in relevé is $40 \%$ ) because of extreme environmental conditions (shallow dry soils and steep slopes) of places where the stands grow. The open vegetation is more prone to introduction of new species such as Populus alba and P. nigra. The stands of the association Polygalo majoris-Brachypodietum pinnati, on the other hand, grow on deeper soils. From a long-term perspective, these conditions fit to some woody species. Also other authors found the overgrowing by woody species as one of the main sign of degradation of dry grasslands (Dostálek, Frantík, 2008; Schrautzer et al., 2009; Hegedüšová, Senko, 2011) or habitat alteration (Smit, 2004). 
Our study confirmed the trend of decline in biodiversity of species-rich dry calcareous grasslands after abandonment of traditional management during recent decades shown in other studies from Central Europe (Galvánek, Lepš, 2008; Schrautzer et al., 2009; Hegedüšová, Senko, 2011; Pipenbaher et al., 2013). From numerous studies, it is clear that the dry calcareous grasslands should receive attention in regard to conservation management (WallisDeVries, 1999; Barbaro et al., 2001; Münzbergová, 2001; Willems, 2001; Kahmen et al., 2002; Riecken et al., 2002; WallisDeVries et al., 2002; Bąba, 2004; Masé, 2005; Bornkamm, 2006; Stadler et al., 2007; Dostálek, Frantík, 2008; Peter et al., 2009; Hegedüšová, Senko 2011; Kuzemko et al., 2016). Our study showed similar conclusions as these studies. As the diversity of dry grasslands in the Devínska Kobyla NNR decreased after the grazing cessation, restoring the grazing should be the part of the conservation management in the area. Grazing is recognized as one of the most natural methods of management of dry grasslands (Hadar et al., 1999; Peter et al., 2009; Hegedüšová, Senko, 2011).

In the last few years, the traditional management has begun to be partly restored in Devínska Kobyla NNR. The biomass of Robinia pseudoacacia L. has been being removed from the year 2016, and the goat grazing was reintroduced in 2017 again. In the recent years, the goats have been grazed also on the steep slopes, where they promote heightened erosion with potentially negative impact on the dry grassland communities. The best possible way is to combine goat and sheep co-grazing on the moderate slopes with removal of the biomass of woody species on the steep slopes. Also other authors (Barbaro et al., 2001; Hegedüšová, Senko, 2011; Bojkovski et al., 2014) found the combination of shrub clearing and grazing as one of the best ways of conservation management of dry grasslands.

\section{Acknowledgements}

This research was supported by the Grant Agency VEGA (Bratislava), Grant No. 1/0885/16 and by the Grant Agency VEGA, Grant No. 1/0767/17. We thank Aaron Fishbone for English grammar proofreading of the manuscript. We would like to thank Mgr. Jozef Kollár, $\mathrm{PhD}$, for his valuable comments and suggestions for improving the manuscript.

\section{References}

Alard, D., Chabrerie, O., Dutoit, T., Roche, P. \& Langlois E. (2005). Patterns of secondary succesion in calcareous grasslands: can we distinguish the influence of former land uses from present vegetation data? Basic and Applied Ecology, 6, 161-173. DOI: 10.1016/j.baae.2005.01.010.

Bąba, W. (2003). Changes in the structure and floristic composition of the limestone grasslands after cutting trees and shrubs and mowing. Acta Soc. Bot. Pol., 72(1), 61-69. DOI: 10.5586/asbp.2003.008.

Bąba, W. (2004). The species composition and dynamics in well-preserved and restored calcareous xerothermic grassland (South Poland). Biologia, 59, 447-456.

Baláž, D. (1994). The succession of xerothermic communities at Devínska Kobyla and their practical protection (in Slovak). Daphne, 2, 6-7.

Barbaro, L., Dutoit, T. \& Cozic P. (2001). A six-year experimental restoration of biodiversity by shrub-clearing and grazing in calcareous grassland of the French Prealps. Biodivers. Conserv., 10, 119-135. DOI: 10.1023/A:1016629507196.

Barkman, J.J., Doin, H. \& Segal S. (1964). Kritische Bemerkungen und Vorschläge zur quantitativen Vegetationsanalyse. Acta Botanica Neerlandica, 13(3), 394-419. DOI: 10.1111/j.1438-8677.1964.tb00164.x.

Bobbink, R., During, H., Schreurs, J., Willems, J. \& Zielman R. (1987). Effects of selective clipping and mowing time on species diversity in chalk grassland. Folia Geobotanica et Phytotaxonomica, 22, 363-376. DOI: 10.1007/ BF02853233. 
Bojkovski, D., Štuhec, I., Kompan, D. \& Zupan M. (2014). The behavior of sheep and goats co-grazing on pasture with different types of vegetation in the karst region. J. Anim. Sci., 92(6), 2752-2758. DOI: 10.2527/jas.2013-7199.

Bornkamm, R. (2006). Fifty years vegetation development of a xerothermic calcareous grassland in Central Europe after heavy disturbance. Flora, 201(4), 249-267. DOI: 10.1016/j.flora.2005.06.012.

Braun-Blanquet, J. (1964). Pflanzensoziologie. Grundzüge der vegetationskunde. Wien, New York: Springer Verlag.

Chytrý, M. (Ed.) (2007). Vegetation of the Czech Republic 1. Grassland and heathland vegetation (in Czech). Praha: Academia.

Domin, K. (1931). Brachypodietum at Kobyla near Bratislava (in Czech). Věda Př́rodní, 12, 57-61.

Dostálek, J. \& Frantík T. (2008). Dry grassland plant diversity conservation using low-intensity sheep and goat grazing management: Case study in Prague (Czech Republic). Biodivers. Conserv., 17, 1439-1454. DOI: 10.1007/ s10531-008-9352-1.

During, H.J. \& Willems J.H. (1984). Diversity models applied to a chalk grassland. Vegetatio, 57, 103-114. DOI: $10.1007 / B F 00047305$.

Dzwonko, Z. \& Loster S. (1998). Dynamics of species richness and composition in a limestone grassland restored after tree cutting. J. Veg. Sci., 9, 387-394. DOI: 10.2307/3237103.

Ellenberg, H., Weber, H.E., Düll, R., Wirth, W., Werner, W. \& Paulissen D. (1992). Zeigerwerte von Pflanzen in Mitteleuropa Ed. 2. Scripta Geobotanica, 18, 1-258.

Feráková, V. \& Kocianová E. (Eds.) (1997). Flora, geology and paleontology of Devínska Kobyla (in Slovak). Bratislava: Litera.

Feráková, V. \& Jarolímek I. (2011). Bratislava. In J.K. Kelcey \& N. Müller (Eds.), Plants and habitats of European cities (pp. 79-129). New York: Springer.

Galvánek, D. \& Lepš J. (2008). Changes of species richness pattern in mountain grasslands: abandonment versus restoration. Biodivers. Conserv., 17, 3241-3253. DOI: 10.1007/s10531-008-9424-2.

Hadar, L., Noy-Meir, I. \& Perevolotsky A. (1999). The effect of shrub clearing and grazing on the composition of a Mediterranean plant community: functional groups versus species. J. Veg. Sci., 10, 673-682. DOI: $10.2307 / 3237082$.

Hajdúk, J. (1986). Results of vegetation changes research on permanent trial plots and their importance for the management of the State Nature Reserve Devínska Kobyla. Ochrana Prírody, 7, 79-105.

Hajdúk, J. (1997). Experimental research and vegetation records on permanent plots at Devínska Kobyla (in Slovak). In V. Feráková \& E. Kocianová (Eds.), Flora, geology and paleontology of Devínska Kobyla (pp. 155-157). Bratislava: Litera.

Hansson, M. \& Fogelfors H. (2000). Management of a seminatural grassland; results from a 15-year-old experiment in southern Sweden. J. Veg. Sci., 11, 31-38. DOI: 10.2307/3236772.

Hegedüšová, K. \& Senko D. (2011). Successional changes of dry grasslands in southwestern Slovakia after 46 years of abandonment. Plant. Biosyst., 145(3), 666-687. DOI: 10.1080/11263504.2011.601605.

Hegedüšová, K. \& Valachovič M. (2015). Vegetation pattern on the western slope of Devínska Kobyla Mts - Southern Slovakia. Phyton, 55(1), 41-68. DOI: 10.12905/0380.phyton55(1)2015-0041.

Hegedüšová-Vantarová, K. \& Škodová I. (Eds.) (2014). Plant communities of Slovakia 5. Grassland vegetation (in Slovak). Bratislava: Veda, vydavatelstvo SAV.

Hennekens, S.M. \& Schaminée J.H.J. (2001). TURBOVEG, a comprehensive data base management system for vegetation data. J. Veg. Sci., 12(4), 589-591. DOI: 10.2307/3237010.

Hill, M.O. (1973). Diversity and evenness: a unifying notation and its consequences. Ecology, 54, 427-432. DOI: $10.2307 / 1934352$.

Hyžný, M., Hudáčková, N., Biskupič, R., Rybár, S., Fuksi, T., Halásová, E., Zágoršek, K., Jamrich, M. \& Ledvák P. (2012). Devínska Kobyla - a window into the Middle Miocene shallow-water marine environments of the Central Paratethys (Vienna Basin, Slovakia). Acta Geologica Slovaca, 4(2), 95-111.

Jacquemyn, H., Van Mechelen, C., Brys, R. \& Honnay O. (2010). Management effects on the vegetation and soil seed bank of calcareous grasslands: An 11-year experiment. Biol. Conserv., 144, 416-422. DOI: 10.1016/j.biocon.2010.09.020.

Janišová, M. (Ed.) 2007. Grassland vegetation of Slovak Republic - electronic expert system for identification of syntaxa. Bratislava: Institute of Botany SAS.

Jarolímek, I. \& Šibík J. (Eds.) (2008). Diagnostic, constant and dominant species of the higher vegetation units of Slovakia. Bratislava: Veda, vydavatelstvo SAV.

Kahmen, S., Poschlod, P. \& Schreiber K.F. (2002). Conservation management of calcareous grasslands. Changes in 
plant species composition and response of functional traits during 25 years. Biol. Conserv., 104, 319-328. DOI: 10.1016/S0006-3207(01)00197-5.

Kaleta, M. (1965). Vegetation terms of Devínska Kobyla (in Slovak). Master's Thesis, Faculty of Natural Sciences, Comenius University, Bratislava.

Köhler, B., Gigon, A., Edwards, P.J., Krüsi, B., Langenauer, R., Lüscher, A. \& Ryser P. (2005). Changes in the species composition and conservation value of limestone grasslands in Northern Switzerland after 22 years of contrasting managements. Perspect Plant Ecol. Evol. Syst., 7, 51-67. DOI: 10.1016/j.ppees.2004.11.003.

Kubíková, J. (1999). Xerothermic lawns and semi-xerothermous forests (in Czech). In V. Petříček (Ed.), Péče o chráněná území I (pp. 213-236). Praha: AOPaK ČR.

Kuzemko, A.A., Steinbauer, M.J., Becker, T., Didukh, Y.P., Dolnik, C., Jeschke, M., Naqinezhad, A., Ugurlu, E., Vassilev, K. \& Dengler J. (2016). Patterns and drivers of phytodiversity in steppe grasslands of Central Podolia (Ukraine). Biodivers. Conserv., 25, 2233-2250. DOI: 10.1007/s10531-016-1060-7.

Maliníková, E. (2003). Xerothermic and sub-xerothermic vegetation of Devinska Kobyla (in Slovak). Master's Thesis, Faculty of Natural Sciences, Comenius University, Bratislava.

Marhold, K. (1998). Ferns and flowering plants. In K. Marhold \& F. Hindák (Eds.), Checklist of non-vascular and vascular plants of Slovakia (pp. 333-687). Bratislava: Veda, vydavatel'stvo SAV.

Masé, G. (2005). The management of dry grassland in Switzerland. A Swiss federal program and its local practical application. Biotechnol. Agron. Soc. Environ., 9(2), 133-138.

Michalko, M. (1977). Forest communities of Devínska Kobyla (in Slovak). Master's Thesis, Faculty of Natural Sciences, Comenius University, Bratislava.

Miškovic, J. \& Dúbravcová Z. (2004a). The community Poo badensis-Festucetum pallentis Klika 1931 corr. Zólyomi 1966 at Devínska Kobyla over 36 years (in Slovak). Bulletin Slovenskej Botanickej Spoločnosti, 26(Suppl. 1), 160-165.

Miškovic, J. \& Dúbravcová Z. (2004b). Changes in the community Ranunculo illyrici-Festucetum valesiacae Klika 1931 at Devínska Kobyla over 36 years (in Slovak). Bulletin Slovenskej Botanickej Spoločnosti, 26, 185-192.

Miškovic, J. (2018). Dynamic changes of grasslands of Devínska Kobyla hill (in Slovak). Dissertation, Faculty of Natural Sciences, Comenius University, Bratislava.

Mojses, M. \& Petrovič F. (2013). Land use changes of historical structures in the agricultural landscape at the local level - Hriňová case study. Ekológia (Bratislava), 32(1), 1-12. DOI : 10.2478/eko-2013-0001.

Münzbergová, Z. (2001). Recovery of species-rich xerothermic lawns on the example of the Stráně u splavu and Stráně u Chroustova reservations (in Czech). Př́roda, 19, 101-121.

Palaj, A. \& Kollár J. (2018). Changes in alpine vegetation over 50 years in the Western Tatras (Slovakia). Ekológia (Bratislava), 37(2), 122-133. DOI: 10.2478/eko-2018-0012.

Peter, M., Gigon, A., Edwards, P.J. \& Lüscher A. (2009). Changes over three decades in the floristic composition of nutrient-poor grasslands in the Swiss Alps. Biodivers. Conserv., 18, 547-567. DOI: 10.1007/s10531-008-9521-2.

Pipenbaher, N., Kaligarič, M., Mason, N.W.H. \& Škornik S. (2013). Dry calcareous grasslands from two neighboring biogeographic regions: relationship between plant traits and rarity. Biodivers. Conserv., 22, 2207-2221. DOI: $10.1007 / \mathrm{s} 10531-013-0520-6$.

Podani, J. (2001). SYN-TAX 2000, Computer program for data analysis in ecology and systematics for Windows 95, 98 \& NT, User's manual. Budapest: Scientia Publishers.

Poschlod, P., Kiefer, S., Tränkle, U., Fischer, S. \& Bonn S. (1998). Plant species richness in calcareous grasslands affected by dispersability in space and time. Appl. Veg. Sci., 1, 75-90. DOI: 10.2307/1479087.

Poschlod, P. \& WallisDeVries M.F. (2002). The historical and socioeconomic perspective of calcareous grasslands. Lessons learnt from the distant and recent past. Biol. Conserv., 104, 361-376. DOI: 10.1016/S00063207(01)00201-4

R Core Team (2018). R: A language and environment for statistical computing. R Foundation for Statistical Computing, Vienna, Austria. Accessed October 22, 2019, from https://www.R-project.org/.

Riecken, U., Finck, P. \& Schröder E. (2002). Significance of pasture landscape for nature conservation and extensive agriculture. In B. Redecker, P. Finck, W. Härdtle, U. Riecken \& E. Schröder (Eds.), Pasture landscape and nature conservation (pp. 423-435). Heidelberg, Berlin: Springer. DOI: 10.1007/978-3-642-55953-2.

Ruprecht, E., Enyedi, M.Z., Eckstein, R.L. \& Donath T.W. (2010). Restorative removal of plant litter and vegetation 40 years after abandonment enhances re-emergence of steppe grassland vegetation. Biol. Conserv., 143, 449-456. DOI: 10.1016/j.biocon.2009.11.012.

Schrautzer, J., Jansen, D., Breurer, M. \& Nelle O. (2009). Succession and management of calcareous dry grasslands in the Northern Franconian Jura, Germany. Tuexenia, 29, 339-351. 
Senko, D., Miškovic, J., Gallay, J,. Senková, M. \& Baldaufová K. (2008). Dynamics of the changes of vegetation at Devínska Kobyla and its prediction (in Slovak). Geografický Časopis, 60, 319-338.

Smit, G.N. (2004). An approach to tree thinning to structure southern African savannas for long-term restoration from bush encroachment. J. Environ. Manag., 71, 179-191. DOI: 10.1016/j.jenvman.2004.02.005.

Stadler, J., Trefflich, A., Brandl, R. \& Klotz S. (2007). Spontaneous regeneration of dry grasslands on set-aside fields. Biodivers. Conserv., 16, 621-630. DOI: 10.1007/s10531-005-0604-z.

Špulerová, J., Drábová, M. \& Lieskovský J. (2016): Traditional agricultural landscape and their management in less favoured areas in Slovakia. Ekológia (Bratislava), 35(1), 1-12. DOI: 10.1515/eko-2016-0001.

Tälle, M., Deák, B., Poschlod, P., Valkó, O., Westerberg, L. \& Milberg P. (2018). Similar effects of different mowing frequencies on the conservation value of semi-natural grasslands in Europe. Biodivers. Conserv., 27, 2451-2475. DOI: $10.1007 /$ s10531-018-1562-6.

Tichý, L. (2002). JUICE, software for vegetation classification. J. Veg. Sci., 13, 451-453. DOI: 10.1111/j.16541103.2002.tb02069.x.

Török, K. \& Szitár K. (2010). Long-term changes of rock grassland communities in Hungary. Community Ecol., 11, 68-76. DOI: 10.1556/ComEc.11.2010.1.10

WallisDeVries, M.F. (1999). The dilemma facing nature conservation and the role of large herbivores. In B. Gerken \& M. Görner (Eds.), The development of European landscapes with large herbivores - history, models and perspectives (pp. 24-31). Natur und Kulturlandschaft 3.

WallisDeVries, M.F., Poschlod, P. \& Willems J.H. (2002). Challenges for the conservation of calcareous grasslands in northwestern Europe: integrating the requirements of flora and fauna. Biol. Conserv., 104, 265-273. DOI: 10.1016/S0006-3207(01)00191-4.

Willems, J.H. (1983). Species composition and above ground phytomass in chalk grassland with different management. Vegetatio, 52, 171-180. DOI: 10.1007/BF00044994.

Willems, J.H. (2001). Problems, approaches, and results in restoration of Dutch calcareous grassland during the last 30 years. Restor. Ecol., 9, 147-154. DOI: 10.1046/j.1526-100x.2001.009002147.x.

Wolkinger, F. \& Plank S. (1981). Dry grasslands of Europe. Strasbourg: Nature and Environment Series.

Zlínska, J. (2004). Adonido-Brachypodietum pinnati (Libbert 1933) Krausch 1961 at Devínska Kobyla (in Slovak). Biosozologia, 2, 49-61. 